Original Contribution

\title{
THE EFFECT OF COW MANURE COMPOST IN CULTIVATION BED AND IRRIGATION WATER SALINITY ON THE GROWTH OF STRELITZIA REGINAE
}

\author{
A. Mohammadi Torkashvand*, H. Khanjani, S. Sedaghat Hoor \\ Department of Horticulture, Rasht Branch, Islamic Azad University, Rasht, Iran
}

\begin{abstract}
To evaluate the possibility cultivating Strelitzia Reginae in the regions having inappropriate quality of irrigation water, an factorial experiment (two factors) was conducted in different growth media containing soil and cow manure compost with or without inorganic fertilization under different salinity of irrigation water base on randomized completely block design. The growth medium containing agricultural soil without inorganic fertilization and this bed with inorganic fertilization, cow manure compost amounted 15, 30, and 45\% v/v instead of agricultural soil in growth medium; and water salinity of $1,2,4$, and $6 \mathrm{dS} \cdot \mathrm{m}^{-1}$, were experiment treatments. Plant growth indices were measured at the end of the 8-month growth period of the plants. The results showed that the increased cow manure compost in the cultivation bed as compared with the application of the inorganic fertilizers, led to the increase of most growth indices of the plant. Moreover, in salinity treatments 1 and $2 \mathrm{dS} . \mathrm{m}^{-1}$ [irrigation water], the measured growth indices showed a relative increase. Generally, adding cow manure compost to cultivation bed of Strelitzia plant can be an appropriate alternative for consumption of inorganic fertilizers and the plant is able to grow with maximum water salinity of $6 \mathrm{dS} \mathrm{m}^{-1}$.
\end{abstract}

Key words: Cow, Manure compost, Inorganic fertilizer, Salinity, Strelitzia reginae

\section{INTRODUCTION}

After aridity, salinity is considered as one of the major environmental stresses in the world, including Iran (1). Today, soil and water salinity is one of the barriers and limitations in utilizing these resources in optimal production of agricultural crops (2). With respect to densely planted crops in agricultural lands, it is necessary to use amendment materials, which provide the available nutrients in soil (3). Today, the use of compost with inorganic fertilizers is recognized as a necessity in creating a sustainable agriculture, because it is able to considerably remove the problems leading to yield reduction of plants and shortage of many required elements of plants such as zinc, phosphorus, potassium in soil (4). As development of the area under cultivation of agricultural crops and amendment of saline lands are limited, it seems that the key to achieve an appropriate performance in saline soils is identification and production of the salttolerant crops, which is an inevitable task (5).

\footnotetext{
*Correspondence to: A. Mohammadi Torkashvand, Department of Horticulture, Rasht Branch, Islamic Azad University, Rasht, Iran,

m.torkashvand54@yahoo.com,Tel: 00989125137128
}

Organic materials are one of the major pillars of soil fertility. The major resources providing organic materials are compost and vermicompost in agriculture. The importance of a sustainable agriculture and reduction of environmental problems using organic materials were highly gained attentions. On the other hand, inorganic fertilizers degrade organic carbon and humus, destroy soil structure, and cause toxicity in plants, which in turn causes spread of some illnesses, such as cancer $(6,7)$. The use of animal manures should not exceed 30-40 tons per hectare, as it may lead to salinity caused by them (8).

\section{MATERIALS AND METHODS}

The experiment was carried out from 14 February 2012 to 16 October 2012 in Pardis Flowers and Plants Production Institute in Abbas Abad, Mazandaran in a greenhouse environment with nylon cover, taking into account the equality of other factors as the factorial based on randomized completely block design with two factors and three replications.

The first factor was the growth medium included agricultural soil without consumption of any fertilizer $\left(\mathrm{A}_{0}=\right.$ control 1$)$, agricultural soil with the 
use of inorganic fertilizer $\left(\mathrm{A}_{1}\right)$, adding different volumes of Cow Manure Compost (CMC) in replacement of agriculture soil in growth medium without inorganic fertilizers $\left(\mathrm{A}_{2}=15 \% \mathrm{v} / \mathrm{v} C M C\right.$, $\mathrm{A}_{3}=30 \% \mathrm{v} / \mathrm{v} \mathrm{CMC}$ and $\left.\mathrm{A}_{4}=45 \% \mathrm{v} / \mathrm{v} \mathrm{CMC}\right)$. The second factor was irrigation water salinity included irrigation by using water available in the region $\left(\mathrm{A}_{2}=\right.$ control 2$)$ and 4 levels of irrigation water salinity $\left(\mathrm{EC}_{1}=1, \mathrm{EC}_{2}=2, \mathrm{EC}_{3}=4\right.$ and $\mathrm{EC}_{4}=6$ $\left.\mathrm{dS} . \mathrm{m}^{-1}\right)$. Seventy five transplant seedlings of Strelitzia reginae identical with same size (produced from seeds) and 30 centimeters height at the 5-leaf stage were cultivated in 4-liter volume pots according to growth medium treatments. After planting the plants in the main beds, irrigation of the plants was performed using normal water of the region for compatibility of roots with new beds for five weeks. Then, the required irrigation (3 times a week) using the region water (control) and different salinities of irrigation water $\left(1,2,4\right.$ and $\left.6 \mathrm{dS} \mathrm{m}^{-1}\right)$ in treatments was performed for 27 weeks. In the treatments of inorganic fertilizer, in turn, urea inorganic fertilizers $46 \%$ and superphosphate were used in ratio of 1:1000 as foliar spray with the same ratio and with irrigation and Kristalon fertilizer (formula $18+18+18+3$ ).

At the end of the 8-month growth period, plant growth indices, such as number of leaves, height of plant (the distance between root-shoot junction and the end of last leaf), crown diameter from 3 $\mathrm{cm}$ above soil surface, lamina surface of trifoliate leaf of the plants were measured using special tools and equipment. After separating root-shoot junction, performing necessary washing, and rinsing with distilled water, the wet weight of root and the washed aerial parts were measured after drying with washing water. They were then put into paper packets and placed in a $75^{\circ} \mathrm{C}$ oven for 48 hours. After this period, the dry weight of each part was measured using a 0.01 accuracy digital scale and registered. At the beginning and at the end of the experiment, $\mathrm{pH}$ and $\mathrm{EC}$ of the cultivation beds were measured using the Verdonck method. Based on this, $400 \mathrm{~cm}^{3}$ of the cultivation bed with volume ratio of 1:5 (one part bed to 5 parts distilled water) was mixed in an Erlenmeyer flask. Then, the samples were put on a shaker for 30 minutes. Finally, extraction was performed using a piece of filter paper. EC contents were measured in the cultivation beds by the saturation extract of beds with water in $10 \mathrm{~cm}$ suction. An Orion $\mathrm{pH}$ meter was used for measuring $\mathrm{pH}$. EC was measured by a Metrohm conductometer in Soil and Water Laboratory of Faculty of Agriculture of Islamic Azad University, Rasht Branch. SPSS and LSD experiment were used to examine the results obtained from the data.

\section{RESULTS AND DISCUSSION \\ 1. The Effect of treatment on $\mathrm{pH}$ and $\mathrm{EC}$ of growth media}

Table 1 and 2 shows the ANOVA results of data related to the impact of treatments on $\mathrm{pH}, \mathrm{EC}$ of growth media and plant growth indices. Results showed that the different quantities of cow manure compost had no significant effect on EC of cultivation bed. However, irrigation water salinity (IWS) had a significant difference in EC of cultivation bed at the level of $1 \%$, so that EC of the control increased from $0.723 \mathrm{dS} . \mathrm{m}^{-1}$ (Table 3) in water salinity treatment of $6 \mathrm{dS} . \mathrm{m}^{-1}$ to $6.54 \mathrm{dSm}^{-1}$. The interaction of cow manure compost and irrigation water salinity on $\mathrm{EC}$ of cultivation bed was not significant at the level of 5\%. CEC contents of cultivation beds with soil are higher than the beds without soil and the ability to retain nutrients of the cultivation beds with soil is higher than the ones without soil. Therefore, these beds are more appropriate for growing the plants with long growing seasons and much irrigation, such as cut flowers and chrysanthemum (9).

The results of data variance analysis (Table 1) showed that there is no significant difference between $\mathrm{pH}$ of the cultivation beds of treatments in the cow manure compost and salinity treatments and their interactions. Garcia stated that compost acts as a buffer to prevent soil acidity (10).

Table 1. Comparing mean-squares of interaction, cultivation bed, and salinity of irrigation water on growth indices of Strelitzia, EC and pH of cultivation bed

\begin{tabular}{lcccccc}
\hline & & \multicolumn{4}{c}{ Mean Squared } \\
\cline { 3 - 6 } Sources of Variations & df & EC & pH & $\begin{array}{c}\text { Dry weight } \\
\text { of root }\end{array}$ & $\begin{array}{c}\text { Number } \\
\text { of leaves }\end{array}$ & Area of leaf \\
\hline A: growth medium & 4 & $0.064^{\text {ns }}$ & $0.704^{\text {ns }}$ & $168.54^{* *}$ & $15.34^{* *}$ & $42100.6^{* *}$ \\
B: Salinity of irrigation water & 4 & $81.147^{* *}$ & $0.878^{\text {ns }}$ & $2.43^{* *}$ & $0.12^{\text {ns }}$ & $1771.5^{* *}$ \\
A $\times$ B & 16 & $0.063^{\text {ns }}$ & $0.899^{\text {ns }}$ & $1.32^{* *}$ & $0.12^{\text {ns }}$ & $340.39^{* * *}$ \\
Error & 48 & 0.023 & 0.735 & 0.09 & 0.025 & 18.41 \\
\hline
\end{tabular}

ns: Not Significant; *: Significant at $\mathrm{P}<0.05$; **: Significant at $\mathrm{P}<0.01$. 
Table 2. Comparing mean-squares of interaction, cultivation bed, and salinity of irrigation water on growth indices of Strelitzia

\begin{tabular}{|c|c|c|c|c|c|c|}
\hline \multirow[b]{2}{*}{ Sources of Variations } & \multirow[b]{2}{*}{ df } & \multicolumn{5}{|c|}{ Mean Squared } \\
\hline & & Height & $\begin{array}{l}\text { Diameter } \\
\text { of stem }\end{array}$ & $\begin{array}{c}\text { Fresh weight } \\
\text { of shoot }\end{array}$ & $\begin{array}{c}\text { Dry weight } \\
\text { of shoot }\end{array}$ & $\begin{array}{c}\text { Fresh weight } \\
\text { of root }\end{array}$ \\
\hline A: growth medium & 4 & $1803.1^{* *}$ & $33.12^{* *}$ & $23477.0^{* *}$ & $4879.5^{* *}$ & $91214.0^{* *}$ \\
\hline EC: Salinity of irrigation water & 4 & $127.07^{* *}$ & $0.95^{\mathrm{ns}}$ & $710.5^{\mathrm{ns}}$ & $95.02^{* *}$ & $1249.3^{* *}$ \\
\hline $\mathrm{A} \times \mathrm{EC}$ & 16 & $18.28^{* * *}$ & $2.33^{\mathrm{ns}}$ & $661.4^{\mathrm{ns}}$ & $61.6^{* *}$ & $562.3^{* *}$ \\
\hline Error & 48 & 0.93 & 1.54 & 382.3 & 1.6 & 40.1 \\
\hline
\end{tabular}

ns: Not Significant; *: Significant at $\mathrm{P}<0.05$; **: Significant at $\mathrm{P}<0.01$.

Table 3. The effect of compost of cow manure and inorganic fertilizer on growth indices of Strelitzia, EC and pH of cultivation bed

\begin{tabular}{cccccc}
\hline Growth media treatment & $\mathrm{EC}$ & $\mathrm{pH}$ & $\begin{array}{c}\text { Water salinity } \\
\text { treatment }\end{array}$ & $\mathrm{EC}$ & $\mathrm{pH}$ \\
\hline $\mathrm{A}_{0}$ (control 1) & $0.723 \mathrm{e}$ & $7.56 \mathrm{a}$ & $\mathrm{EC}_{\mathrm{r}}($ Control 2) & $0.723 \mathrm{e}$ & $7.05 \mathrm{a}$ \\
$\mathrm{A}_{1}$ (inorganic fertilizer) & $0.674 \mathrm{e}$ & $7.63 \mathrm{a}$ & $\mathrm{EC}_{1}$ & $1.265 \mathrm{~d}$ & $7.6 \mathrm{a}$ \\
$\mathrm{A}_{2}$ & $0.728 \mathrm{e}$ & $7.62 \mathrm{a}$ & $\mathrm{EC}_{2}$ & $2.408 \mathrm{c}$ & $7.58 \mathrm{a}$ \\
$\mathrm{A}_{3}$ & $0.896 \mathrm{e}$ & $7.11 \mathrm{a}$ & $\mathrm{EC}_{3}$ & $4.566 \mathrm{~b}$ & $7.6 \mathrm{a}$ \\
$\mathrm{A}_{4}$ & $0.781 \mathrm{e}$ & $7.5 \mathrm{a}$ & $\mathrm{EC}_{4}$ & $6.540 \mathrm{a}$ & $7.58 \mathrm{a}$ \\
\hline
\end{tabular}

\section{The Effect of Cultivation Bed}

The results comparing mean of treatments (Table 4) showed that maximum height, maximum fresh and dry weight, number of leaves, lamina surface of leaves and diameter of shoot were obtained in the 45 percent cow manure compost (v/v). In the lower treatments of cow manure compost (15\% and $30 \%$ ), the significant increase of growth was seen in all the indices. Growth of shoot was registered at all the levels treated with cow manure compost with a relatively high and significant difference in proportion to control treatments (agricultural soil and inorganic fertilizer). Alam (2004) stated that if the organic materials available in any kind of soil are sufficient, the plant cultivated in that soil is rarely subjected to shortage of nutrient elements (4). At the beginning, composts contain high amount of nutrients and high activity of the microbial population in the rhizosphere area of root improves growth. Composts contain high levels of humic materials and they can act as growth substances (11). The advantage to use compost is that it contains nutrients, mainly nitrogen and potassium. Therefore, they act as slow- release organic fertilizers. Composts contain the materials that regulate plant growth and are able to neutralize soil-borne pathogens of plants. They usually show porosity and holding capacity of stoma up to a high level and they have a low water holding capacity. In addition, they contain rich amounts of salt and nutrients (12).

Table 4. Effect of treatments on the growth indices of Strelitzia

\begin{tabular}{ccccccccc}
\hline treatment & $\begin{array}{c}\text { Height } \\
(\mathrm{cm})\end{array}$ & $\begin{array}{c}\text { Diagonal } \\
\text { of stem } \\
(\mathrm{cm})\end{array}$ & $\begin{array}{c}\text { Number } \\
\text { of } \\
\text { leaves }\end{array}$ & $\begin{array}{c}\text { Area } \\
\text { of leaf } \\
\left(\mathrm{cm}^{2}\right)\end{array}$ & $\begin{array}{c}\text { fresh } \\
\text { weight of } \\
\text { shoot }(\mathrm{g})\end{array}$ & $\begin{array}{c}\text { Dry } \\
\text { weight of } \\
\text { shoot }(\mathrm{g})\end{array}$ & $\begin{array}{c}\text { Dry } \\
\text { weight of } \\
\text { root }(\mathrm{g})\end{array}$ & $\begin{array}{c}\text { fresh } \\
\text { weight of } \\
\text { root }(\mathrm{g})\end{array}$ \\
\hline $\mathrm{A}_{0}$ (control 1) & $52.46 \mathrm{e}$ & $8.36 \mathrm{c}$ & $9.0 \mathrm{e}$ & $115.9 \mathrm{e}$ & $80.1 \mathrm{~d}$ & $36.44 \mathrm{~d}$ & $6.23 \mathrm{~d}$ & $125.24 \mathrm{~d}$ \\
$\mathrm{~A}_{1}$ (inorganic fertilizer) & $78.1 \mathrm{~b}$ & $9.96 \mathrm{~b}$ & $12.4 \mathrm{~b}$ & $233.6 \mathrm{c}$ & $178.2 \mathrm{a}$ & $36.15 \mathrm{a}$ & $9.87 \mathrm{c}$ & $217.97 \mathrm{c}$ \\
$\mathrm{A}_{2}$ & $68.84 \mathrm{~d}$ & $10.36 \mathrm{~b}$ & $11.5 \mathrm{bc}$ & $85.1 \mathrm{~d}$ & $149.0 \mathrm{c}$ & $66.1 \mathrm{c}$ & $9.97 \mathrm{c}$ & $219.92 \mathrm{c}$ \\
$\mathrm{A}_{3}$ & $73.52 \mathrm{c}$ & $11.49 \mathrm{a}$ & $11.6 \mathrm{bc}$ & $237.6 \mathrm{~b}$ & $162.6 \mathrm{bc}$ & $79.59 \mathrm{a}$ & $12.62 \mathrm{~b}$ & $278.16 \mathrm{~b}$ \\
$\mathrm{~A}_{4}$ & $79.77 \mathrm{a}$ & $12.22 \mathrm{a}$ & $13 \mathrm{a}$ & $251.2 \mathrm{a}$ & $170.8 \mathrm{ab}$ & $74.79 \mathrm{~b}$ & $15.18 \mathrm{a}$ & $334.48 \mathrm{a}$ \\
& & & & & & & & \\
$\mathrm{EC}_{\mathrm{r}}($ Control 2) & $71.96 \mathrm{~b}$ & $10.14 \mathrm{a}$ & $9.0 \mathrm{e}$ & $210.6 \mathrm{a}$ & $151.2 \mathrm{ab}$ & $69.67 \mathrm{a}$ & $11.04 \mathrm{a}$ & $243.31 \mathrm{a}$ \\
$\mathrm{EC}_{1}$ & $71.2 \mathrm{c}$ & $10.76 \mathrm{a}$ & $9.9 \mathrm{~d}$ & $207.4 \mathrm{~b}$ & $151.5 \mathrm{ab}$ & $67.31 \mathrm{~b}$ & $10.97 \mathrm{a}$ & $283.32 \mathrm{~b}$ \\
$\mathrm{EC}_{2}$ & $73.86 \mathrm{a}$ & $10.68 \mathrm{a}$ & $9.7 \mathrm{~d}$ & $206.4 \mathrm{~b}$ & $153.1 \mathrm{a}$ & $69.62 \mathrm{a}$ & $11.08 \mathrm{a}$ & $240.67 \mathrm{~b}$ \\
$\mathrm{EC}_{3}$ & $69.54 \mathrm{~d}$ & $10.46 \mathrm{a}$ & $9.1 \mathrm{e}$ & $194.5 \mathrm{c}$ & $148.8 \mathrm{a}$ & $65.52 \mathrm{c}$ & $10.66 \mathrm{~b}$ & $233.24 \mathrm{c}$ \\
$\mathrm{EC}_{4}$ & $66.14 \mathrm{e}$ & $10.34 \mathrm{a}$ & $9.0 \mathrm{e}$ & $184.7 \mathrm{~d}$ & $136.1 \mathrm{~b}$ & $63.95 \mathrm{~d}$ & $10.11 \mathrm{c}$ & $220.24 \mathrm{~d}$ \\
\hline
\end{tabular}


It might be due to having high amount of salt, $\mathrm{pH}$ and herbal toxicity or heavy metals that some compost are not suitable for consumption as the main component of cultivation bed. However, depending on the basic composition, composts can be used as a valuable source of nutrition. The composts used as beds for systems producing greenhouse ornamentals should be stable and accessible (13). Having inhibitory feature, composts prevent soil-borne diseases. Generally, they improve physical, inorganic, and biological features of beds (14).

\section{The Effect of Irrigation Water Salinity (IWS)}

According to the results (Table 5), Strelitzia had the maximum growth in $2 \mathrm{dS} . \mathrm{m}^{-1}$ salinity. Growth reduction was seen in the IWS less and higher than $2 \mathrm{dS} . \mathrm{m}^{-1}$. The reduction was significant in IWS 4 and $6 \mathrm{dS} . \mathrm{m}^{-1}$; however, it did not stop growth. The effect of salinity on a plant depends on several factors, namely species, genotypes, plant growth stages, salt composition, and environmental factors (15).

As the data showed, the highest indices of growth were obtained in water salinity of 2 and $1 \mathrm{dS} . \mathrm{m}^{-1}$. The maximum $(73.86 \mathrm{~cm})$ and minimum heights $(66.14 \mathrm{~cm})$ were respectively obtained at salinity treatment of 2 and $6 \mathrm{dS} . \mathrm{m}^{-1}$. The salinity is caused to decrease the length of stems (16). Crown diameter of treatments 1 and $2 \mathrm{dS} \cdot \mathrm{m}^{-1}$, with 10.76 and $10.68 \mathrm{~cm}$ were respectively the maximum diameters. The minimum diameter $(10.14 \mathrm{~cm})$ was seen in the control. The heaviest fresh weight of the aerial parts $(153.07 \mathrm{~g})$ and dry weight of root $(11.08 \mathrm{~g})$ were obtained in salinity $2 \mathrm{dS} . \mathrm{m}^{-1}$. The growth indices reduced in the lower and higher salinities; however, growth stop was not observed. Hasandokht stated that growing ornamentals in pot beds is realized in the salinities between $1-3 \mathrm{ds} \mathrm{m}^{-1}$ (17).

\section{Interaction effect of Irrigation Water Salinity and cultivation bed}

Pay attention to Table 4, results showed that the growth indices in soil bed with foliar spray of inorganic fertilizer mostly increased than in the soil bed without fertilization. In both beds, the height of plant in IWS $0.45 \mathrm{dS} / \mathrm{m}$ was more than IWS $6 \mathrm{dS} / \mathrm{m}$, but in control bed without fertilizer, $12.68 \%$ decrease in height of IWS $6 \mathrm{dS} / \mathrm{m}$ was observed than in IWS $0.45 \mathrm{dS} / \mathrm{m}$. This decrease in height was $5.86 \%$ in soil bed with fertilization. One of the ways to reduce the detrimental effects of salt stress, the use of mineral nutrition $(18,19)$
This is an important point that the increase in IWS of control treatment without fertilization caused to a considerable change in the growth indices of plant (excluding height). This indicates the high tolerance of Strelitzia Reginae to salinity, therefore, results denote to the possibility cultivating Strelitzia Reginae in areas having the low quality (salinity) of irrigation water at least in short periods. In soil bed with inorganic fertilizer, the height of plant showed a considerable increase than in the soil bed without fertilization that can be due to the availability soil nutrients and the appropriate nutrition of plant. At this treatment, increase in IWS to $6 \mathrm{dS} / \mathrm{m}$ led to significant decrease in some growth indices, but this is not considerable than in the absolute yield. Thus, fertilization had a more importance than salinity at this treatment on the growth of plant.

The yield of shoot in $15 \%$ compost has reduced than in the soil treatment with inorganic fertilizer, and in addition to decreasing height, it is observed a decrease in the number and area of leaves, fresh and dry weight of shoot. This indicates that $15 \%$ compost could not play the same role of inorganic fertilizers in plant nutrition. Increasing IWS caused to decrease fresh and dry weight of roots in $15 \%$ compost treatment, significantly. Compost is rich in nutrients and produces growth hormones during microbial decomposition. On the other hand, the composts have the salinity impact in the growth media. It seems that the use of $15 \%$ compost has not promoted the productivity of bed same to inorganic (chemical) fertilizers. Also, salinity resulted of compost has decreased the growth of shoot. At root environ; the simultaneous effect of salinity of compost and IWS reduced the growth of root.

The growth in 45\% compost showed a considerable increase in compared with $15 \%$ compost and soil treatment with inorganic fertilizer. This can be due to nutritional role of cow manure compost that is more than inorganic fertilizer at this amount; on the other hand, it is observed a decrease in all indices of growth with increasing IWS due to the salinity effect of compost. Meanwhile, the growth at IWS $6 \mathrm{dS} / \mathrm{m}$ of $45 \%$ compost bed is very higher than control without fertilization. If we consider the shoot growth as a criterion, the soil treatment with inorganic fertilizer had the further yield than in the $45 \%$ compost in IWS $6 \mathrm{dS} / \mathrm{m}$, therefore, it seems that the use of soil as a medium of Strelitzia Reginae with inorganic fertilizer is a better bed. 
Table 5. The interaction effect of growth medium and water salinity on EC, $p H$ and plant growth indices

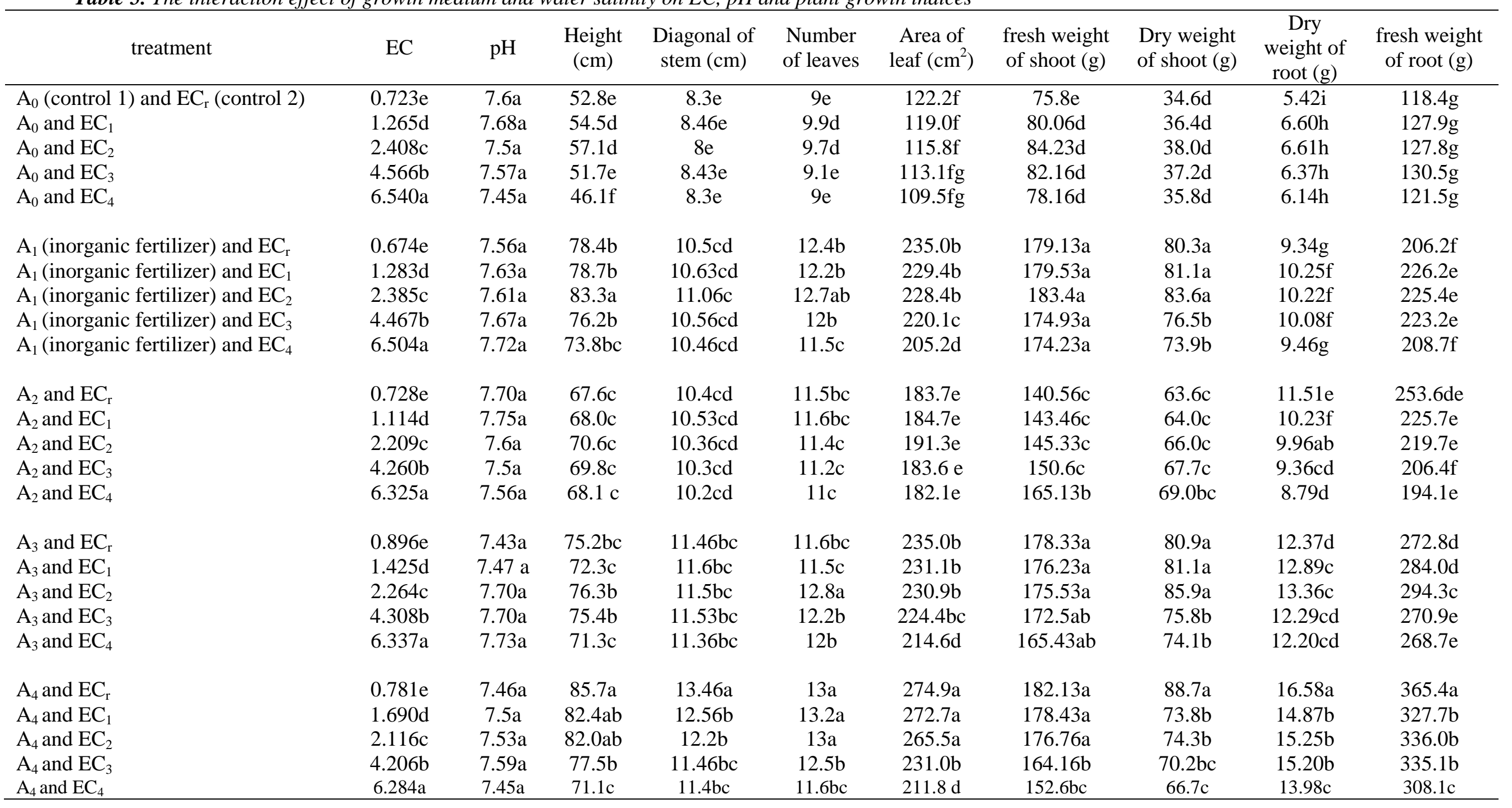




\section{CONCLUSION}

Results showed that the use of inorganic fertilizer in soil bed increases the growth of plant than this bed without fertilization. According to results, Strelitzia Reginae had the high tolerance to salinity of irrigation water and in many growth indices at soil treatments and lower compost, it was not observed the considerable difference between IWS of control $(0.45 \mathrm{dS} / \mathrm{m})$ and IWS $6 \mathrm{dS} / \mathrm{m}$. Using lower compost such $15 \%$ in growth medium cannot play similar role of inorganic (chemical) fertilizer on the growth of plant, but using $45 \%$ compost had a more effect on the growth than in the chemical fertilizer, therefore, in IWS $6 \mathrm{dS} / \mathrm{m}$ the growth of shoot in soil treatment with inorganic fertilizer is better than $45 \%$ compost. Totally, $45 \%$ compost treatment is appropriate bed for Strelitzia Reginae, but IWS $6 \mathrm{dS} / \mathrm{m}$ is not proposed at this bed.

\section{ACKNOWLEDGMENT}

Financial support by Rasht Branch, Islamic Azad University Grant No. 4.5830 is gratefully acknowledged.

\section{REFERENCES}

1. Akhani, H., Ghorbanli, M., A contribution to the halophytic vegetable and flora of Iran. In: H. Leith and A.A. Al Massom (eds). Towards the Rational Use of High Salinity Tolerant Plants, 1; 35-44, 1993.

2. Homaei, M., Reaction of Plants to Salinity, Iranian National Committee on Irrigation and Drainage (IRNCID), Tehran, 97 pages, 1993.

3. Malakouti, G., Balali, M.R., Optimal Consumption of Fertilizers for Sustainability in Agricultural Productions, Agriculture Training Publications, Karaj, 575 pages, 2004.

4. Alam, S.M., 'Azolla' agreen compost for rice. The DAWN Group of News Pepers. 2004.

5. Mc William, J.R., The national and international importance of drought and salinity effects on agricultural production. Australian $J$ Plant Physiol, 13, 1-13, 1986.

6. Zarrinkafsh, M.N., Lajevardi. S. Inorganic and Organic Fertilizers. (Translation). Aboureihan Publications, Tehran, Iran, 1987.
7. Ghosh, P.K., Ajay, K.K., Bandyopadhyay, M.C., Manna, K.G., Mandal, A.K., Hati, K.M., Comprativeeffectivence of cattle manure, poultry manure, phosphocompost and fertilizerNPK on three cropping system in vertisols of semi-arid tropics.П. Dry matter yield, nodulation, chlorophyll content and enzyme activity. Bioresource Technol. 95; 85-93, 2004.

8. Mohammadi Torkashvand, A., General Pedology. Islamic Azad University Publications, Rasht Branch, 264 pages, 2009.

9. Dole, J.M., Wilkins, F.H., Floriculture. Part 2. 2 thed. Prentice Hall. 304-318. 1999.

10.Garcia-Prendes, R., Evalution of dairy manure compost as a peat substitute in poting media for container grown plant. MSc. Thesis, University of Florida. 2001.

11.Lee, Z.S., Bartlett, R.J., Stimulation of plant growth by humic substances. Soil Sci Soc Am J, 40; 876-879, 1976.

12.Garcia, A., Gomez, M., Bernal, P., Roig, A., Growth of ornamental plants in two composts prepared from agroindustrial wastes. Bioresource Technol, 83, 81-87, 2002.

13.Wilson, S.B., Stoffella, P.J., Graetz, D.A., Use of compost as a media amendment for containnerized production of two subtropical perennials. J Environ Hort, 19(1); 37-42, 2001.

14.Wilson, S.B., Stoffella, P.J., Compost amended media and irrigation system influence containerized perennial Salvia. Am Soc Hort Sci, 128(2); 260-268, 2003.

15.Greenway H., Munns R., Mechanisms of salt tolerance in nonhalophytes. Annu. Rev. Plant Physiol, 31; 149-190, 1980.

16.Oki, L.R., Lieth, J.H., Effect of changes in substrate salinity on the elongation of rosahybrida L. Kardinal stems. Sci Hort. 101; 103-119, 2004.

17.Hasandokht, M., Greenhouse Management, Marz-e-Danesh Publications. P. 98-108, 2005.

18. Marschener, H. 1995. Mineral nutrition of higher plant. Second Academic Press London. 100-150. pp.

19.Raven, J.A., Transport and function of silicon in Plants. Biol. Rev. 58; 179-207, 1983. 
